\title{
İbnü'l-Arabî'nin Nûr-i Muhammedî Açısından Hz. Muhammed ve Diğer Peygamberler Arasındaki İlişkilere Bakışı
}

View of Ibn al-Arabī on Muhammad (pbuh) and Other Prophets in terms of Light of Muhammad

Doç. Dr.

Veysel AKKAYA

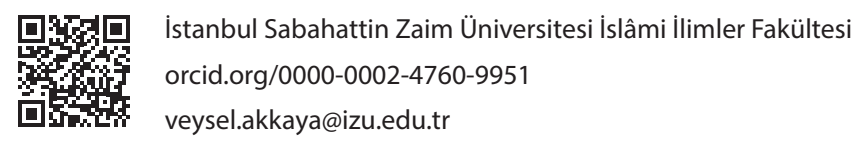




\section{Sufinge}

180

Öz

Tasavvufta Nûr-i Muhammedî konusu ilk dönemden itibaren mutasavvıfların ve müfessirlerin bazı âyet ve hadisler ışı̆̆ında dikkat çektikleri bir husustur. Sûfîlere göre Nûr-i Muhammedî, Allah'ın ilk yarattığı varlığın adı olmasından dolayı, farklı din, mezhep ve kültürlerde yer alan ilk varlık hakkındaki düşüncelerle karşılaştırılmıştır. Bu konuda İbnü'l-Arabî’nin eserlerinde, mutlak Varlık'ın ilk tezâhürü olarak Nûr-i Muhammedî ile ilgili açıklamalara geniş̧̧e yer verdiği görülmektedir. İbnü’l-Arabî Varlık ve mertebelerini açıklarken, Hakk'ın varlı̆̆ının ilk taayyünü olarak Nûr-i Muhammedî’nin yaratılan ilk varlık olduğunu ve diğer varlıkların bu nurdan yaratıldığını söyler. İlk yaratılan şey ile ilgili kalem, akıl, ruh, arş gibi farklı isimlendirmeleri aslında bir hakîkatin farklı yönleri olarak gören İbnü'l-Arabî, böylece ilk yaratılış ile ilgili bütün görüşleri kendi ontolojisinde birleştirir. Günümüzde konu ile ilgili yerli ve yabancı ilmî çalışmalar bulunmaktadır. Bu çalışmada, Nûr-i Muhammedî ile peygamberler arasındaki ilişki incelenecektir.

Anahtar Kelimeler: Nûr-i Muhammedî, Hakîkat-i Muhammediyye, Sirâc, Mişkât, Cevâmiu'lkelim, Felek, Zevk, Mizaç.

\section{Abstract}

The subject of the light of Muḥammad in Șūfīsm is an issue that Șūfīs and commentators have drawn attention to in the light of certain verses and hadiths since the early periods. It has been compared with the thoughts about the first being in different religions, sects, and cultures since the light of Muhammad is the name of the first being created by Allah according to the șüfìs. Ibn al-Arabì broadly addresses the light of Muhammad as the first manifestation of the absolute Being in his works. Explaining the ranks of Being, He states that the light of Muhammad, as the first emergence of the existence of God, is the first being created and other beings are created from this light. Ibn al-Arabī, who considers different names such as al-kalam, al-aql, the soul, and the throne (Arsh) as the first thing created as different aspects of truth, unites all the views about the first creation in his ontology. There are domestic and international studies on the topic. In this study, the relationship between the light of Muhammad and the prophets will be analyzed.

Keywords: The Light of Muhammadī, 'Haqiqat al- Muhammadiyya, Cresset, The Lamp, Jawāmi` al-Kalim, Orbit, Enjoyment, Temperament. 


\section{Giriş}

üşünce tarihinin temel meselelerinden biri de "Varlık" ın anlamlandırilması olmuştur. Bu hususta tarih boyunca din, mezhep ve kültürler farklı değerlendirmelerde bulunmuştur. Ancak bu değerlendirmelerin bir kısmı İbnü'l-Arabî̀ye göre hakîkî anlamlarını kaybetmiş durumda olduğundan, yeniden aslına uygun bir tarzda ele almak, hakîkatleri ortaya çıkarmak için Kur'ân ve Sünnet'in tasdik ettiği keşfî bilgiye ihtiyaç vardır. ${ }^{1}$

Varlık açısından Allah, âlem ve insanın ne ifade ettiği, yaratılan ilk varlığın ne olduğu hususunda başta İbnü’l-Arabî olmak üzere, sûfîlerin de kendilerine özgü yöntemlerle görüş beyan etmelerini, oryantalistlerin de savunduğu gibi, ${ }^{2}$ sadece başka görüşlerden etkilenme ve onların izini sürme şeklinde değerlendirmek, ${ }^{3}$ İslâm'ın evrenselliği ve insanlığın ortak meseleleri ile ilgili hakîkatlerin ortaya konması hususunda müslüman âlimlerin söz sahibi olması ile bağdaşmayacaktır. İslâm daha önce var olan hakikatleri tasdik etmiş, bâtıl olanları reddetmiş ve yanlış olanları da tashih etmiştir. Bu açıdan hâkîkatlerin farklı inanç ve düşünce sistemlerinde orijinalliğini kaybetmiş olması, bir başka deyişle tevhidden uzaklaştırılmasıyla karşılaşan Müslüman âlimlerin, o hakîkatleri Kur'ân ve sünnet merkezli yeniden inşâ ederek, tevhid çerçevesinde açılamaya çalışmaları, meseleleri aslına ircâ etme gayretleri ve entelektüel düzeyde tehvîde davetleri olarak değerlendirilebilir.

Tasavvuf metafiziğine göre hakîkî varlık sadece Allah'a aittir. "el-Vücûd” sıfatı tek mutlak varlığın Allah olduğunu, varlığın hakîkî manada Allah'a âit olduğunu ifade eder. Âlemin varlığı ise Allah'ın varlığının

1. Bkz. Mahmud Erol Kılıç, Muhyiddin İbnü’l-Arabî, Türkiye Diyanet Vakfi İslâm Ansiklopedisi (İstanbul: TDV Yayınları, 1999), 20/496-487; Mahmud Erol Kılıç, Şeyh-i Ekber İbn Arabi Düşüncesine Giriş (İstanbul: Sufi Kitap, 2009), 90-93; 144-147.

2. Bkz. Ignaz Goldziher, "Hadis'te Yeni Eflatuncu ve Gnostik Unsurlar”, çev. Ömer Özsoy, Ankara Üniversitesi İlahiyat Fakültesi Dergisi 36 (1997), 405-421; Soner Akpınar, "Oryantalist Düşüncede Hakîkat-i Muhammediyye Algıs1 - Ignaz Goldziher ve Annemarie Schimmel Örneği”, Kahramanmaraş Sütçü İmam Üniversitesi İlahiyat Fakültesi Dergisi 16/ 32 (2018), 279-309.

3. Bkz. Ebü'l-A'la Afifi, Fusûsü'l-hikem li'ş-Şeyhi'l-Ekber Muhyiddîn b. Arabîve't-ta'likâtu aleyh (Beyrut: Dârü'l-Hayât, 1946), 2/319-320; Rifat Okudan, "Hakikat-i Muhammediyye: Felsefî Temelleri ve Dînî Asıllarının Değerlendirilmesi”, Süleyman Demirel Üniversitesi İlahiyat Fakültesi Dergisi 11/2 (2003), 158-160; Mahmut Ay, "İşari Tefsirlerde Hakikat-i Muhammediyye Anlayışı”, Darulfunun İlahiyat: İstanbul Üniversitesi İlahiyat Fakültesi Dergisi 23/2 (2010), 111; Mustafa Akman, "Hakikat-ı Muhammedi Düşüncesi ve Bu Düşüncenin Referanslarını Aktaran İki Kaynak ve Müellifleri”, Yalova Sosyal Bilimler Dergisi 2/2 (2011), 111. 
tecellilerinden ibarettir. Allah'ın âlemi yaratmasının başlangıcı hususunda İbnü'l-Arabî başta olmak üzere ekberî irfânı takip eden sûfîler, Allah'in el-Evvel oluşunun varlıkta tezâhürü gereğince her şeyin bir ilki olacağından, varlığın açılımına kaynaklık edecek bu ilk varlığın ne olduğu hususunu bazı âyet ve hadisler ışı̆̆ında izah etmektedirler. Konuyu izah sadedinde çekirdek-ağaç gibi semboller kullanarak, âlemde birlikten çokluğa, çokluktan da birliğe doğru bir akış olduğu üzerinde durmuşlardır. Birlik asıl iken çokluk onun tezahürlerinden ibarettir. Bu tezâhürler sonunda yine birliğe döner. Bu durum tasavvuf düşüncesinde "vahdette kesret, kesrette vahdet" şeklinde formüle edilmiştir.

Varlık'nn tezâhürü konusuna esmâ-i hüsnâ açısından bakıldığında, ism-i câmî olarak Allah ismi bütün isimlerin kaynağıdır. Her bir isim tezâhürü bakımından çokluğa delâlet ederken, zâtı itibarıyla birliğe delâlet eder. Esmâ-i hüsnânın yaratılanlarda tezâhürü de birlik ve çokluk şeklindedir. Sûfîler varlık âlemi içerisinde bütün isimleri câmi' olan Allah isminin ilk ve en büyük mazharının Peygamber Efendimiz (s.a.v.) olduğu görüşündedirler. Dolayısıyla din, mezhep ve kültürlerde faklı görüşlerin yer aldığı ilk yaratılan varlık hakkında sûfîler, bu varlığın Rasûlüllah'ın nûru, bir başka deyişle rûhu ve hakîkati olduğunu belirtmişlerdir. ${ }^{4}$

Varlık ve mertebeleri konusunda en geniş açılımlarıyla bilgi verenlerin başında İbnü’l-Arabî gelmektedir. O Varlık olarak (el-Vücûd) hakîkî manada sadece Allah'ın var olduğunu belirtir. O halde bizim varlık olarak isimlendirdiğimiz şeyler, gerçek Varlık karşısında ne ifade etmektedir, sorusu karşımıza çıkmaktadır. İşte bu noktada onun cevabı, bu varlıkların gerçek Varlık'ın farklı mertebelerdeki tezâhürü olduğu şeklindedir. Varlık'in her bir mertebede tezâhürü vahdetten kesrete doğru akış şeklindedir. "Bütün her şey O’na döner" 5 âyeti gereği varlığın bu açılımını aynı zamanda kesretten vahdete akışı izleyecektir. Hakk'ın varlığının ilk mertebede tezâhürü -ki buna "taayyün-i evvel" de denir- Allah ism-i şerîfinin vahdet halinde tecellisi olan ilk hakîkat, ilk nûr olup, bu nûr da Hz. Pegyamber'in nûrudur.

Sûfîlerin bu görüşe ulaşmasında hiç şüphesiz bazı âyet ve hadisler kaynaklık etmiştir. Nûr-i Muhammedî konusunun anlaşılması için Kur'ân ve Hadis'te "nûr" kavramının genel olarak çerçevesi, hangi varlıkların

4. Bkz. Kılıç, “Muhyiddin İbnü’l-Arabî”, 20/496-497.

5. Âl-i İmrân 3/109. 
nûr olarak isimlendirildiği ve ayrıca Hz. Peygamber ile ilgisinin hangi boyutlarda olduğunun bilinmesi gerekir. ${ }^{6}$ Nûr-i Muhammedî görüşünün bağlamından koparılarak, bazı etkilerle sonradan ortaya çıkmış yeni bir mesele gibi değerlendirilmesinin gerçeği yansıtmayacağı ortadadır. Biz makalemizin mahdut sınırları içerisinde İbnü'l-Arabî'den önceki dönemde Nûr-i Muhammedî ile ilgili görüşlere kısaca temas ettikten sonra, makalemizi İbnü'l-Arabî̀nin Nûr-i Muhammedî’nin diğer peygamberlerin nûru arasındaki ilişkisine bakışıyla sınırlı tutacağız. ${ }^{7}$

\section{1. İbnü’l-Arabî'den Önceki Dönemde Nûr-i Muhammedî İle İlgili Görüşler}

Kur'ân-ı Kerîm'de "nûr" kavramı Allah Teâlâ ve bazı varlıklar için kullanılmış olup farklı manalar içermektedir. ${ }^{8}$ en-Nûr ismi yirmi dördüncü sûreye ad olmuştur. Nûr âyeti olarak bilinen 35. âyette ise "nûr" Allah'ın zâtına izafe edilmiştir. Ayrıca "en-Nûr" ismi Allah Teâlâ’nın esmâ-i hüsnâsından biridir. ${ }^{9}$ Buna göre hatıllanması gereken ilk husus, âyette geçtiği üzere, ${ }^{10}$ esmâ-i ilâhiyyenin insan dışındaki varlıklarda tecellisi bazı isimlerle iken, insandaki tecellisinin bütün isimlerle olmasıdır. İkinci husus

\footnotetext{
6. Bu konuda bir çalışma için bkz. Ömer Çelik, "Kur’ân-1 Kerîm’de Nûr Kavramı”, Marmara Üniversitesi İlahiyat Fakültesi Dergisi 16-17 (1998-1999), 149-155; Salih Çift, "İlk Dönem Tasavvuf Düşüncesinde Nûr Kavramı”, Uludă̆ Üniversitesi İlahiyat Fakültesi Dergisi 13/1 (2004), 144-146; Azat Karimov, Kur'ân'da Nur Kavramı (Ankara: Ankara Üniversitesi, Sosyal Bilimler Enstitüsü, Yüksek Lisans tezi, 2012).

7. Konu ile ilgili diğer çalışmalar için bkz. Michel Chodkiewicz, "Seal of the Saints: Prophethood and Sainthood in the Doctrine of Ibn 'Arabi", çev. Liadain Sherrard (Lahore: Suhail Academy, 2001), 60-73; Selçuk Eraydın, "Hakîkat-i Muhammediyye” Diyânet Dergisi 25/4 (1989), 131143; Mehmet Demirci, "Hakîkat-i Muhammediyye”, Türkiye Diyanet Vakfi İslâm Ansiklopedisi (İstanbul: TDV Yayınları, 1997), 27/179-180); Mehmet Demirci, "Nûr-i Muhammedî”, Dokuz Eylül Üniversitesi İlahiyat Fakültesi Dergisi 1/1 (1983), 239-258; Kılıç, İbn Arabî Düşüncesine Giriş, 298-308; Rifat Okudan, "Hakîkat-i Muhammediyye: Felsefî Temelleri ve Dînî Asıllarının Değerlendirilmesi”, Süleyman Demirel Üniversitesi İlahiyat Fakültesi Dergisi 11/2 (2003), 139-164; Rifat Okudan, “Hz. Peygamber'den İlk Yaratılan Şey Hakkında Rivayet Edilen Hadisler Işı̆̆ında Hakikat-i Muhammediyye”, VI. Kutlu Doğum Sempozyumu (Isparta: SDÜ İlahiyat Fakültesi İslâm Felsefesi Ana Bilim Dalı, 2006), 165-178; Nuran Döner, Tasavvuf Kültüründe Hz. Peygamber Tasavvuru (Bursa: Uludağ Üniversitesi, Sosyal Bilimler Enstitüsü, Doktora Tezi, 2007), 12-46; Suad el-Hakîm, Mu'cemu's-Sûfî (Beyrût: Dâru Nedre, 1981), 347-348; Schimmel, Annemarie, ve Muhammed Onun Elçisi'dir, çev. Ekrem Demirli (İstanbul: Kabalcı Yayınevi, 2011).

8. Çelik, "Nûr Kavramı", 123-171.

9. Tirmizî, "Da'avât”, 82.

10. “...ve Âdem’e bütün isimleri ögretti” el-Bakara 2/31.
} 
ise Allah'ın göklerin ve yerin nûru olarak, ${ }^{11}$ bütün varlıklarda nûrunun tecellî etmekte olduğudur. ${ }^{12}$ Bu ön bilgiler bizi bütün ilâhî isimlerin en kâmil tecellisinin Peygamberimiz'de olduğu sonucuna götürmektedir. Çünkü o hadislerde "Ademoğlunun en üstünü”13, “...Allah katında öncekilerin ve sonrakilerin en kıymetlisi"14 hatta varlıkların en hayırlısı ${ }^{15}$ olarak haber verilmektedir. Konuya nûr açısından bakılacak olursa Hz. Rasûlüllah'ın, nûr-i ilâhînin en büyük mazharı olarak varlıklara izâfe edilen en büyük nûrun sahibi olduğunu söylemek mümkündür. Ayrıca Hz. Rasûlüllah'ın âlemlere rahmet oluşu ${ }^{16}$ ile birlikte düşünüldüğünde, Nûr-i Muhammedînin diğer bütün varlıklar ile ilişkili olduğu anlaşılmaktadır. İslâm âlimleri ve özellikle sûfîler ilk dönemlerden itibaren Muhammedî nûra işâret eden âyet ve hadislere dikkat çekmişlerdir. Meselâ Mukâtil b. Süleyman, (ö. 150/767) Nûr sûresindeki Allah'ın nûrunun misâlini Muhammed'in nûru olarak izah etmektedir. ${ }^{17}$ Mâide sûresinin 15. âyetinde bahsedilen “... Gerçekten size Allah'tan bir nûr, apaçık bir kitap geldi” âyetindeki "nûr" ile ilgili, Taberî (ö. 310/923) ve Râzî (ö. 606/1210) başta olmak üzere bazı müfessirlerin açıklamalarından biri de kastedilenin $\mathrm{Hz}$. Resûlüllah olduğudur. ${ }^{18}$ Bir başka âyette Peygamberimiz'in vasıflarından biri "sirâc-ı münîr", ${ }^{19}$ nûr yayan bir kandildir. Kandilin nûr yayması için elbette içinde nûr bulunması gerekir. Bu hususta Fahreddîn er-Râzî, Peygamberimiz için "güneş” değil de "sirâc/kandil” ifadesinin kullanılmasının ince hikmetler taşıdığını söyler. Ona göre güneşin nurundan alınamaz, ancak kandilin nurundan birçok nurlar alınarak başkaları tutuşturulur. ${ }^{20}$

11. en-Nûr 24/35.

12. Geniş bilgi için bkz. Çelik, "Nûr Kavramı”, 136-143.

13. Tirmizî, "Menâkıb”, 1 (No. 3610).

14. Tirmizî, "Menâkıb”, 1 (No. 3616); Dârimî, "Mukaddime”, 8 (No. 48). Peygamberimiz’in üstünlüğü ile ilgili geniş bilgi için bkz. Kâdî İyâz, Şifa-i Şerif, çev. Mehmet Yaşar Kandemir (İstanbul: Tahlil Yayınları, 2012), 1/196-198.

15. “...mahlûkâtın en hayırlısı...”Tirmizî, “Menâkıb”, 1 (No. 3607).

16. el-Enbiyâ 21/107.

17. Ebû Hüseyin Mukâtil b. Süleyman, Tefsîru Mukâtil b. Süleyman, thk. Abdullah Mahmud (Beyrut: Dâru İhyâi't-Türâs, 1423/2002), 3/199.

18. Bkz. Ebu Ca'fer et-Taberi, Tefsîru't-Taberî, thk. Abdulllah b. Abdulmuhsin (Riyâd: Dâru'lâlemi'l-İslâmî, 2003), 7/264; Fahreddîn Râzî de âyetteki “nûr ve kitap” ile ilgili şu görüşlere yer verir: "Âyetteki "nûr" ile, Hz. Muhammed (s.a.v.); "kitap" ile de Kur’ân-1 Kerîm; "Nûr" ile İslâm, "kitap” ile Kur'ân; "Nûr” ile de, "kitap” ile de Kur'ân-1 Kerîm kastedilmiştir." Bkz. Fahreddîn er-Râzî, Tefsîr-i Kebîr, çev. Kurul (Ankara: Akçă̆ Yayınları, 1988), 8/548.

19. el-Ahzâb 33/45-46.

20. Bkz. Râzî, Tefsîr-i Kebîr, 18/273. 
Rasûlüllah (s.a.v.)'in Allah katından getirdiği bu nûr insanları küfür, şirk ve cehâlet gibi bütün karanlıklardan kurtararak aydınlığa çıkaran, Allah’a giden hidâyet yolunu aydınlatan bir nûrdur. "O öyle aydınlatıcı bir kandildir ki, ashâb-1 kiramdan itibaren kıyâmete kadar gelecek bütün mü’minler, gönül kandillerini O’nun nûruyla tutuşturacaklardır."21

Hadislerde de konu ile ilgili bilgiler bulunmaktadır. ${ }^{22}$ Meselâ ilk peygamber oluşu ile ilgili sahih bir hadiste de şöyle buyrulur: "Âdem, rûh ile ceset arasinda iken ben Peygamberdim." ${ }^{23}$ Yine diğer bir hadiste: "Ben yaratılışta nebîlerin ilkiyim ve peygamber olarak gönderilişte ise sonuncusuyum" ${ }^{24}$ buyrulmuştur. Bu hadîslerden anlaşılan Peygamberimizin rûhâniyet yönüyle peygamberlerin ilki olması onun rûhen bütün peygamberlerin ilki, bedenen ise sonuncusu olduğudur. Ayrıca konu ile ilgili şöyle bir rivâyet de vardır: "Kureyş Hz. Âdem yaratılmadan iki bin yıl önce

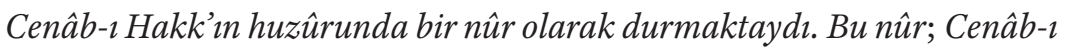
Hakkı tesbîh eder, melekler de onun tesbîhi sebebiyle Allah'ı tesbîh ederdi. Allah Teâlâ Hz. Âdem'i yaratınca, bu nûru onun sulbüne iletti. Bundan sonrası hakkında Resûl-i Ekrem sallallahu aleyhi ve sellem şöyle buyurdu: 'Allah Teâlâ beni Âdem'in sulbünde yeryüzüne indirdi. Sonra beni Nûh'un sulbüne koydu, daha sonra İbrahim'in sulbüne iletti. Böylece Allah Teâlâ beni hep asîl sulblerden, tertemiz rahimlerden birbirine ileterek, kesinlikle evlilik dışı ilişkide bulunmamıs olan anne ile babamdan dünyaya getirdi" 25

Nûr-i Muhammediyye/Hakîkat-i Muhammediyye konusunda sûfîlerin ilk dönemden itibaren açıklamalar yaptığı bilinmektedir. ${ }^{26}$ Tasavvufî $^{2}$ araştırmalarda Muhammedî nûr kavramına çoğunlukla ilk kez Zünnûn

21. Çelik, "Nûr Kavramı”, 169; 149-150.

22. İlgili hadisler ve değerlendirmeleri için bkz. Okudan, “Hz. Peygamber'den İlk Yaratılan Şey Hakkında", 165-178; Okudan, "Hakikat-i Muhammediyye", 149-158.

23. Tirmizî, “Menâkıb”, 1 (No. 3609); Ahmed b. Hanbel, Müsned, 4/66; 5/59.

24. Ebü'l-Hayr Şemsüddîn es-Sehâvî; el-Makasıdü'l-Hasene, thk. Muhammed Osman el-Huşt (Beyrut: Dârü'l-Kitâbi'l-Arabi, 1985), 1/520 (No. 837); İbn Kesir bu hadisin Katâde'den mürsel olarak rivayet edildiğini, bazılarının ise mevkuf dediğini söyler. Ebü’l-Fidâ İmâdüddîn İbn Kesîr, Tefsirü'l-Kur'âni'l-azim, thk. Muhammed Hüseyin Şemsüddin (Beyrut: Dâru'l-Kütübi'lİlmiyye, 1998), 6/342.

25. Bkz. İbni Hacer el-Askalânî, el-Metâlibü'l-âliye, thk. Habiburrahman el-A'zamî (Kuveyt: el-Matbaatü'l-Asriyye, 1973); 4/177, (No. 4256) (Askalânîye göre bu hadis zayıftır.) Kâdî İyâz bu rivayeti destekler mahiyette, delil olarak Efendimiz hakkında amcası Hz. Abbas'ın Peygamberimiz hakkındaki meşhur şiirini gösterir. bkz. Kâdî İyâz, Kitâbü̉ş-şifa bi-ta'rifi'l-hukuki'l-Mustafa (Kahire: Dâru'l-Hadîs, 1977), 1/58.

26. Bu konuda geniş bilgi için bkz. Çift, “İlk Dönem Tasavvuf Düşüncesinde Nûr Kavramı”, 139-158. 
el-Misrî (ö. $245 / 859$ [?]) ${ }^{27}$ veya Abdullah et- Tüsterî̀de (ö. 283/896) ${ }^{28}$ rastlandığı söylenilse de, aslında ilk defa Câfer es-Sâdık'ta (ö. 148/765) rastlandı̆̆ına dikkat çekilmiştir. ${ }^{29}$

Câfer es-Sâdık, Kalem sûresinin ilk âyetindeki hurûf-ı mukattaa'dan olan "nûn” harfini tevil ederken, bu harfin Nûr-i Muhammedî̀ ye işaret ettiğini belirtmiş ve o nûrun "bütün nûrların kendisinden yaratıldığg ezeliyet nûru” olduğunu söylemiştir. Ayrıca Kalem sûresi dördüncü âyette geçen "Sen büyük bir "huluk” üzeresin” âyetindeki "huluk” kelimesini "nûr" olarak te’vîl etmiştir. Bu yoruma göre âyetin mânâsı "Sen ezelde sana tahsîs edilen "nûr" üzeresin" şeklinde olmaktadır. ${ }^{30}$

Meşhur zâhidlerden Sehl b. Abdullah et-Tüsterî’nin ise “Ĕger Allah’ı seviyorsanız bana uyunuz ki Allah da sizi sevsin"31 âyetini izah ederken "Peygamberlerin, melekûtun, dünyâ ve âhiretin nûru onun nûrundandır. Kim hakîkî muhabbet istiyorsa ona uysun" diyerek, ${ }^{32}$ Nûr-i Muhammedî ile irtibat kurup, onun nûrunun aydınlığında olmanın muhabbetin bir gereği olduğuna dikkat çektiği söylenebilir. Hallâc'a göre ise nübüvvet nûrları Hz. Muhammed'in nûrundan ortaya çıkmış olup, bu nûrlar onun nûru ile zâhir olurlar. Nûrlar içinde onun nûrundan daha belirgini yoktur ve onun nûrundan daha önce bir nûr bulunmaz. ${ }^{33}$

27. Okudan, "Hadisler Işı̆̆ında Hakikat-i Muhammediyye”, 267.

28. Demirci, "Nûr-1 Muhammedî", 1/239.

29. Bkz. Chodkiewicz, Seal of the Saints, 65. Burada şunu da hatırlatmak gerekir; sahabiler Peygamber Efendimiz ve evlâdını "nûr" olarak nitelediklerinden, Hz. Osman "zü’n-nûreyn” (iki nur sahibi) lakabı ile anılmıştır.

30. Câfer es-Sâdık, Hakâiku't-Tefsîri'l-Kur'ânî, haz. Ali Zey'ur (Beyrut: Müessesetu İzzeddin, 1993), 84, 179; ayrıca bkz. Ebû Abdurrahman es-Sülemî, Hakâiku't-Tefsîr, thk. Gerhard Böwerıng (Beyrut: Dârü'l-Maşrık, 1995), 205.

31. Âl-i İmrân 3/31.

32. "Ben yeryüzünde bir halife yaratacă̆ım" (el-Bakara 2/30) âyetinde "Allah Âdem'i izzet toprağından, Muhammed'in nûrundan yarattı” der. Bkz. Abdullah et-Tüsteri, Tefsîrü't-Tüsterî (Beyrut: Dârü'l-Kütübi'l-İlmiyye, 2002), 27 “..Rabbin Adem oğullarından, onların bellerinden zürriyetlerini çıkardı, onları kendilerine şahit tuttu.." (el-A'râf 7/172) âyetinde "zürriyetler" şeklinde geçmesine dikkat çekerek onu üçe ayırır. Birincisi Muhammed'dir. Çünkü Allah, Muhammed'i yaratmayı murad edince, onu nûrundan, nûr olarak rzhâr etmiştir. Tüsterî, Tefsîr, 68-69; "Onun nûrunun misâli" (en-Nûr 24/35) âyetinde "Muhammed'in nûru gibidir" der. Tüsterî, Tefsîr, 111; "Sidreyi örten örtmekte iken" en-Necm 53/16 âyetinde ise sidrenin Muhammed'in nûrundan olduğunu söyler. Tüsterî, Tefsîr, 156.

33. Ebu'l-Mugis el-Hüseyn b. Mansûr Al-Hallâj, Kitâb al-Tawâsin/Kitâbu’t-Tavâsîn, Préparé; Louis Massignon (Paris: Librairie Paul Geuthner, 1913), 11. 
Gazzâlî (ö. 505/1111) de nurlar hiyerarşisinden bahsettiği kitabında sirâc-1 münîri anlatırken Rasûlüllah’ın (s.a.v.), tüm peygamberlerin ve âlimlerin "sirâc" 1 olduğunu, ancak aralarında sayılamayacak çok farklılıklar bulunduğunu belirtir. ${ }^{34}$ Görüldüğ̈̈ üzere daha önceki bazı sûfîler Hz. Peygamber'in nûru ile bütün peygamberlerin nûrunun ilişkisine dikkat çekmişlerdir.

\section{2. İbnü'l-Arabî'nin Nûr-i Muhammedî Açısından Peygamberlere Bakışı}

Sûfiler içerisinde Nûr-i Muhammedî konusunun en geniş izahı İbnü’lArabî'de (ö. 638/1240) görülür. ${ }^{35}$ Onun açıklamalarında Hz. Peygamber'in âlemlere rahmet olarak gönderilişi ${ }^{36}$ gibi âyetlerin ve insanların en üstünü, ${ }^{37}$ hattâ bütün varlıkların en üstünü, ${ }^{38}$ efendisi oluşu gibi hadislerin temel dayanak teşkil ettiği anlaşılmaktadır. İbnü’l-Arabî’nin konu ile ilgili anlatımları bu üstünlüğü ve efendiliği çeşitli yönleriyle açıklamak şeklindedir. İbnü'l-Arabî Vücûd (Varlık) mertebelerini ${ }^{39}$ açıllarken "Nûr-i

\footnotetext{
34. Ebû Hamîd el-Gazzâlî, Mişkâtü’l-Envâr (Beyrut: Dâru'l-Kütübi'l-İlmiyye, 1994), 5; İlhan Kutluer, “Felsefe ile Tasavvuf Arasında: Gazzâlî’nin Mişkatü’l-Envar'ında Entellektüel Perspektifler”, 900. Vefat Yılında İmam Gazzâlî: Milletlerarası Tartışmalı İlmi Toplantı (İstanbul: Marmara Üniversitesi İlahiyat Vakfı Yayınları: 2012), 577-519.

35. Bu durumun İbnü’l-Arabî’nin bâzı müşâhedelerinde bütün resûl ve nebîlerin hakîkatlerini görmüş olması ile yakından ilgili olduğu söylenebilir. Geniş bilgi için bkz. Muhyiddin İbnü’lArabî, Fusûsu'l-Hikem, thk. Ebu'l-Alâ Afîfî (Tahran: İnşârâtü'z-Zehrâ, 1370), 110; İbnü'l-Arabî bu müşâhedesinden Fütûhât'ta da bahseder. Bkz. Muhyiddin İbnü'l-Arabî, el-Fütûhâtü'l-Mekkiyye (Beyrût: Dâru Sâdır, ts.) 3/208; 323; 4/77; Konu ile ilgili değerlendirme için bkz. Claude Addas, İbn Arabi, çev. Atila Ataman (İstanbul: Gelenek Yayıncılık, 2003), 91-105.

36. el-Enbiyâ 21/107.

37. Tirmizî, "Menâkıb” 1 (No. 3616); Dârimî, "Mukaddime”, 8 (No. 48).

38. “...mahlûkâtın en hayırlısı...” Tirmizî, “Menâkıb”, 1 (No. 3607).

39. İbnü'l-Arabî’nin düşüncesinde Hakk'ın zuhûru mertebelere göre tasnîfler yapılarak îzâh edilir. Bu mertebeler üçlü, dörtlü, beşli, yedili, kırklı hattâ yüzlü mertebeler şeklinde tafsîlatlandırılarak anlatılmıştır. Geniş bilgi için bkz. Kılıç, Şeyh-i Ekber, 185-325; Bu konuda geniş bilgi için bkz. İbnü’l-Arabî, Fütûhât, 2/421-470; Abdülkerîm el-Cîlî, el-İnsânu'l-Kâmil (Beyrût: Dâru'l-Kütübü'l-İlmiyye, 1997); Abdülkerîm el-Cîlî, İnsân-ı Kâmil, çev. Abdülaziz Mecdi Tolun, haz. Selçuk Eraydın vd. (İstanbul: İz yayınları, 2002); Abdülkâdir el-Cezâirî, Buğyetü't-Tâlib alâ Tertîbi't-Tecellî bi Külliyyeti’l-Merâtib. haz. Asım İbrahim el-Keyyali (Beyrut: Darü'l-Kütübi'l-İlmiyye, 1425/2004) el-Cezâirî bu kitabında İbnü'l-Arabî’nin eserlerine dayalı olarak, mertebeleri detaylı bir şekilde açıklar. Ayrıca bkz., Ahmet Avni Konuk, Muhyîddîn İbnu'l-Arabî Fusûsu'l-Hikem Tercüme ve Şerhi haz. Mustafa Tahralı - Selçuk Eraydın (İstanbul: MÜIİF Yayınları, 1996), 1/4-89.
} 
Muhammedî”yi Varlık mertebelerinde birinci taayyüne yerleştirir. Hakk’ın varlığının Zât mertebesinden ilk taayyün/tecellî yeri ile ilgili "vâhidiyet, hazret-i rubûbiyyet, âlem-i gayb, âlem-i ulvî, âlem-i emr, âlem-i melekût, âlem-i bâtın, âlem-i esmâ...” gibi birçok isim kullanılmıştır. Bunun sebebi ise ona göre tek olan hakîkatin çok çeşitli yönlerinin olmasıdır. ${ }^{40}$ Dolayısıyla Nûr-i Muhammedî bütün bu vasıfların sahibidir.

Muhammedî nûrun ilk yaratılan olmasını İbnü’l-Arabî, hadîslerde geçen Allah'ın ilk yarattığı şey ile ilişkilendirir. İlk yaratılan şey ile ilgili;

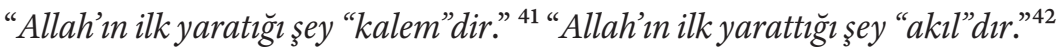
gibi farklı rivâyetler bulunmaktadır. İlk bakışta çelişki gibi görülen bu rivâyetler İbnü'l-Arabî’ye göre aslında bir olan hakîkati açıklığa kavuşturmaktadır. Çünkü farklı rivâyetler farklı îtbârlar açısından bir hakîkatin değişik yönlerine işaret etmektedir. Böylece Hakîkat-i Muhammediyye’nin farklı yönleri anlaşılmış olmaktadır. Bununla birlikte hepsinde kastedilen aslında bir tek hakîkat ${ }^{43}$ olup o da Hakîkat-i Muhammediyye'dir. Bu konuda İbnü’l-Arabî şöyle der: “...Bize göre Hakîkat-i Muhammediyye, başkalarına göre ilk Akıl'dır. İlk Akıl ise Allah Teâlâ’nın bir şey olmadan var ettiği "Yüce Kalem”dir...” 44 “O tafsîl lisânı yönünden “Akıl”dır. Tedvîn

40. Kılıç, “İbnü’l-Arabî”, 20/502. Konu ile ilgili ayrıca bkz. Konuk, Fusûsu'l-Hikem Tercüme ve Şerhi, 1/11-13; Abdulkerim el-Cîlî, el-İnsânu'l-Kâmil (Beyrut: Dâru'l-Kütübi'l-İlmiyye, 1997), 48-50; İhsan Kara, Tasavvuf ıstılahlarn literatürü ve Seyyid Mustafa Râsim Efendinin Istılahât-ı İnsân-ı Kâmil'i (İstanbul, Marmara Üniversitesi, Sosyal Bilimler Enstitüsü, Doktora Tezi, İstanbul, 2003), 227; Demirci, "Hakîkat-i Muhammediyye" 15/179-180.; "Hakîkat-i muhammediye"ye başka isimlerin verilmesini Abdülkerim el-Cîlî "nisbet”le açıklar. Çünkü "rûh-i muhammedî, akl-i evvel ve kalem-i a'lâ tâbirleriyle kastedilen tek cevher olup mahlûka nisbetle ona "kalem-i a'lâ"; yaratılış gāyesine nisbetle "akl-1 evvel" denildiği gibi, insân-ı kâmile nisbetle de "rûh-i muhammedî” ismini alır." Cîlî, el-İnsânu'l-Kâmil, 146.

41. Hakim en-Nisaburi, Müstedrek, thk. Mustafa Abdulkadir Atâ (Beyrut: Dâru'l-Kütübi'lİlmiyye, 1990), 2/454.

42. Bedreddin el-Aynî, Umdetü'l-Kârîşerhi Sahîhi l-Buhârî (Kahire: İdâretü't-Tibâati'l-Münîriyye, ts.), 7/214; Ebü'l-Kâsım Süleymân et-Taberânî, el-Mu'cemu'l-Evsat (Kahire: Dâru'l-Harameyn, 1415), 8/283; Ahmed b. Hüseyin el-Beyhakî, Şuabu'l-İman (Beyrut: Dâru'l-Kütübi'l-İlmiyye, 1410), 4/154; Ebû Nuaym el-İsfahânî, Hilyetü'l-Evliyâ (Beyrut: Dâru'l-Kütübi'l-Arabî, 1405), 7/318. 43. Cîlî bu ifâdeye "cevher-i ferd" adını verir. bkz. el-Cîlî, el-İnsânu'l-Kâmil, 146.

44. İbnü'l-Arabî, Fütûhât, 1/94; İbnü'l-Arabî, Resâilü İbn Arab̂̂ (Kitâbu'l-Mesâil). 307, hâşiye: Muhammed Abdülkerim en-Nemrî (Beyrût: Dâru'l-Kütübi'l-i̇lmiyye, 2004); Muhammed Abdülkerîm en-Nemrî, Ukletü'l-müstevfiz (Beyrut: Dâru'l-Kütübi'l-İlmiye, 2005), 51, 52; "Mukayyed, fakîr olarak var olan ilk varlık, İlk Akıl diye isimlendirilir. Ayrıca o Rûh-i küllî, Kalem, Adl, Arş, el-Hak el-Mahlûk bihi, Hakikat-i Muhammediyye, Rûhu'l-ervah, İmamü'lmübin ve her şey diye isimlendirilir. Onun kendisindeki yönler sebebiyle bir isimleri çoktur." 
ve tastîr (yazma ve satır hâline getirme) yönüyle "Kalem"45, tasarruf yönüyle "Rûh", istivâ yönüyle "Arş", ihsâ ve rekâik (saymak ve hakîkatle olan ince bağları) yönüyle de "İmâm-ı mübı̂n"dir."46

İbnü'l-Arabî yaratmanın başlangıcı olan heb $\hat{a}^{47}$ dan ilk mevcud olanın Hakîkat-i Muhammediyye olduğunu söyler. ${ }^{48}$ İbnü'l-Arabî Peygamberimiz' in ilk oluşunu peygamberlerin miftâhı benzetmesiyle de açıklar ve Peygamberliğin rûhâniyet olarak ilk onunla açıldığını kasteder. ${ }^{49}$ Bu manada bütün nebî ve resûllerin rûhâniyetine yardım, Hz. Peygamberin temiz rûhâniyetinden gelmektedir. Peygamberler nübüvvetle görevlendirildikleri zaman ilim ve şerîatlarını Peygamberimizin rûhâniyetiyle ızhâr ederler. ${ }^{50}$

İbnü'l-Arabî’nin Peygamberimiz'in diğer peygamberlerle ilişkisi hususunda "Biz seni ancak âlemlere rahmet olarak gönderdik." âyetine istinad etmesi, onun konunun en geniş sınırlarını belirlemesi açısından dikkate değerdir. Âlemlerin Rabbi olan ve Rahmeti her şeyi kuşatan Allah, ${ }^{52}$ habîbi Hz. Peygamber'i bütün âlemlere ve her şeye rahmet olarak göndermesi, onun varlıklar içerisinde en üst pâyeye sahip olmasının açık göstergesidir. Ayrıca âyette bir zaman sınırı konmamış olması da önemli bir husus olup, Allah'ın rahmet tecellisini görünen ve görünmeyen bütün âlemlerde, Hz. Peygamber ile gerçekleştirmesi, onun âlemlerle müstesnâ ilişkisini ve aynı zamanda efendiliğini göstermektedir. Allah'ın “er-Rahmân" ismi bütün isimleri içine aldığı gibi, rahmetin de bütün tecellîleri içine aldığ 1 anlaşılmaktadır. O halde böyle bir rahmetin baş tecellisi olan Hz. Peygamber bütün ilâhî kemâl vasıfların kendisinde toplandığı kişi olmaktadır. Bu noktada İbnü’l-Arabî, varlığa Hz. Peygamber ile yayılan rahmetin geçmiş ve geleceği kapsadığı kanaatinde olup, aynı zamanda Hz. Resûlüllah'ın peygamberliğinin umûmîliğine de işaret saymıştır. Ona

Hadîslerde geçen farklı ifâdelerin değerlendirilmesi için ayrıca bkz. Abdülkerim el-Cîlî, Şerhu Müşkilâti'l-Fütûhâti'l-Mekkiyye, thk. Yusuf Zeydan (Kâhire: Dârü'l-Emin, 1999), 74.

45. Kalem ve Levh, tedvîn ve tastîr âlemidir. Bkz. Mahmûd el-Gurâb, Rahmetün mine’r-Rahmân (Dımaşk: Matbaatü Nazar, 1989), 4/362.

46. İbnü'l-Arabî, Ukle, 52, İbnü'l-Arabî, Kitâbu'l-mesâil, 308.

47. "Hebâ, içinde murad edilen şekil ve sûretlerin meydâna getirilmesi için lüzümlu olan binanın harcı ve toprağı mertebesindedir.” İbnü’l-Arabî, Fütûhât, 1/119.

48. bkz. İbnü'l-Arabî, Fütûhât, $1 / 119$

49. bkz. İbnü'l-Arabî, Kitâbu'l-İsrâ İlâ Makāmi'l-Esrâ, 175

50. İbnü'l-Arabî, Fütûhât, 1/135.

51. el-Enbiyâ 21/107.

52. el-A'râf $7 / 156$. 
göre bu umûmîlik diğer bütün peygamberleri de kapsar. Bu rahmet vasfı aynı zamanda Hz. Peygamberin resûllerin en kâmili ve üstünü oluşuna da delil teşkil eder. ${ }^{53}$

Hz. Peygamber'in âyette "hâtemü’n-nebiyyîn" ${ }^{54}$ şeklinde peygamberlerin sonuncusu olduğunun bildirilmesi, İbnü'l-Arabî’de aynı zamanda kendinden önceki bütün peygamberlerin kemâlini de kendinde toplaması anlamına gelir. Çünkü "hatm" kelimesi meşhur son anlamının yanında, bir şeyin ulaşabileceği son haddi anlamında da olunca, peygamberlikte ulaşılabilecek nihâî kemâle işâret eder. ${ }^{55}$ Her bir kemâlin kendisinde son bulduğu peygamberlerden bahseden İbnü'l-Arabî, nübüvvetin hatminin Hz. Muhammed'de, velâyetin hatminin Hz. Îsâ'da, hilâfetin hatminin Hz. Süleyman'da olduğunu söylediği gibi, bütün bu ve diğer peygamberlerdeki kemallerin tamamının hatminin Peygamberimiz'de olduğunu söyleyerek onun için "hatmü'l-hatm", sonların sonu tabirini kullanır. ${ }^{56}$

İbnü'l-Arabî̀nin Nûr-i Muhammedî ile diğer peygamberlerin ilişkisini kurduğu bir âyet de Hz. Peygamber'in sîrâc/kandil oluşudur. ${ }^{57}$ Ona göre bu âyetten anlaşılan bütün peygamberlerin nûrlarını ve ilimlerini kendisinden aldıkları sirâc/kandil Hz. Muhammed'dir. ${ }^{58}$ İbnü'l-Arabî, konuyu açıklamak için bir başka âyette Allah'ın güneşi sirâc yapması$\mathrm{n}^{59}$ hatırlatarak tıpkı bunun gibi Hz. Peygamber'in de bir mânevî güneş olarak sirâc oluşuna dikkat çeker. Hz. Peygamber bu özelliğii ile Hak'tan aldığ 1 ilâhî vahyin nûrunu insanlara ulaştırmaktadır. ${ }^{60} \mathrm{~Hz}$. Peygamber' in güneş gibi bir nûra sahip oluşunu, güneşin gündüz ortaya çıkışına kıyas yapan İbnü'l-Arabî̀ye göre, diğer varlıkların nûrlarının güneşin nûru karşısında ona dâhil olması gibi, Hz. Peygamber'in bir güneş gibi ortaya

53. bkz. İbnü'l-Arabî, Fütûhât, 3/568-569.

54. el-Ahzâb 33/40.

55. bkz. Suâd el-Hakîm, Mu'cemu's-Sûfî (Beyrut: Dâru Nedre, 1981), 373-374.

56. Hakîm, Mu'cemu's-Sûfî̀, 375.

57. el-Ahzâb 33/46.

58. bkz. İbnü'l-Arabî, Fusûs, 63-64; İbnü'l-Arabî, Fütûhât, 4/326; Cîlî konu ile ilgili olarak, küllî Hakîkat-i Muhammediyyenin her peygamber ve velîde hakîkat ve şuhûd olarak mevcut olduğunu, hakîkatte Hz. Peygamber'in rûhunun rûhu'l-ervâh olduğu için Şeyh'in onu "Sirâc" olarak vasıflandırdı̆̆ını söyler. Geniş bilgi için bkz. Cîlî, Şerhu Müşkilât, 73.

59. el-Furkân 25/61.

60. bkz. İbnü'l-Arabî, Fütûhât, $1 / 642$. 
çıkmasıyla birlikte diğer nebîlerin nûru, bu nûra dâhil olmuş, böylece efendiliği bâtında iken zâhir olmuştur. ${ }^{61}$

İbnü'l-Arabî ayrıca Hz. Peygamber'i güneşe, diğer peygamberleri de yıldıza benzetir. Bu konuda sahâbî şâir Nâbiğa el-Ca'dî̀nin ${ }^{62}$ bir melik için söylediği şiiri, Hz. Peygamberin nûrunu ifâde etmek husûsunda güzel bulduğu için aktarır:

Sen güneş gibisin melikler ise yıldızlar

\section{Sen doğunca görünmez olur onlar63}

İbnü'l-Arabî bu benzetme ile Peygamberimiz'in şeriatıyla birlikte diğer şeriatların ona katıldığını ve onun şeriatının içerisinde bulunduğu için bir hükmünün kalmadığını da açıklamış olmaktadır. Ona göre daha önceki şeriatların Hz. Resûlüllah'ın şeriatına dâhil olması, yıldızların 1şıklarının güneşin ışığına katılmasına benzer. ${ }^{64}$

Bir âyette Hz. Peygamber mişkâta/lambaya ${ }^{65}$ benzetilmesini yorumlayan İbnü'l-Arabî, bütün peygamberlerin sâhip oldukları ilimleri, her ne kadar bedenî varlığ̣ daha sonra olsa da hakîkatiyle var olduğu için Hâtemü'n-Nebîyyîn'in mişkâtından aldıklarını ifâde eder. ${ }^{66}$ Cismiyle gönderilinceye kadar rûhaniyetiyle (ister nebî ister resul olsun) bütün peygamberlerin ruhlarına makamını veren de Peygamberimiz'dir. ${ }^{67}$

İbnü'l-Arabî bu görüşlerinin bir netîcesi olarak, Peygamberimiz ve diğer peygamberler arasındaki irtibatı, Peygamberimiz’e nâzil olan Kur'ân

61. bkz. İbnü'l-Arabî, Fütûhât, 1/ 137.

62. Aynı lakab ile birkaç meşhûr Arap şâiri vardır. Buradaki şâir Nâbiğa el-Ca'dî olup İbnü’lArabî onun şiirinden sıkça bahseder. bkz. İbnü'l-Arabî, Fütûhât, 1/145, 492; İbnü'l-Arabî, Fütûhât 2/184; Nâbiga el-Ca'dî el-Âmirî, Necid'in güneyindeki Felec'de doğmuştur. 630 yılında Hz. Peygamber'in huzûruna gelip müslüman olarak bir methiye (Râiyye) okumuş ve Hz. Peygamberin duâsına mazhar olmuştur. Geniş bilgi için bkz. Zülfikar Tüccar, "Nâbiga elCa'dî” Türkiye Diyanet Vakfi İslâm Ansiklopedisi (İstanbul: TDV Yayınları, 2006), 32/260-261. Hakkında müstakil çalışmalar yapılmıştır. bkz., Halil İbrâhim Ebû Ziyab, en-Nâbiga el-Ca'di (Dımaşk: Dârü'l-Kalem, 1987); Ahmed Hasan Besbah, en-Nâbigatüll-Ca’di (Beyrut: Dârü̈lKütübi'l-İlmiyye, 1994); Hz. Ömer onu insanların şiiri en iyi bileni olarak ve şâirlerin şâiri olarak övmüştür. Müttakî el-Hindî, Kenzü’l-Ummâl (Beyrût: Müessesetü’r-Risâle, 1989), 3/1413. 63. bkz. İbnü’l-Arabî, Fütûhât, 1/145, 492; İbnü'l-Arabî, Fütûhât, 2/184.

64. bkz. İbnü'l-Arabî, Fütûhât, 1/145.

65. en-Nûr 24/35; Ayrıca âlem ve insân-1 kâmilin, Rahmân'ın nûrunun zuhûru için bir "mişkât" olduğu söylenir. Geniş bilgi için bkz., Abdürrezzâk el-Kâşânî, Letâifu'l-A'lâm, tsh. Mecîd Hâdîzâde (Tahran: Merkez-i Neşr-i Mîrâs-1 Mektûb, 2000), 534.

66. İbnü'l-Arabî, Fusûs, 63-64.

67. İbnü'l-Arabî, Resâilü İbn Arabî: Risâletü'l-Envâr, haz. Muhammed Abdülkerim en-Nemrî (Beyrût: Dâru'l-Kütübi'l-İlmiyye, 2004), 130. 
ile diğer peygamberlere gönderilen ilâhî kitaplar ve sâhifeler arasında da kurar. İbnü’l-Arabî “Kur'ân” kelimesinin iştikaklarından birinin de “cem’/ toplamak" olmasından hareketle şöyle der: "Kur'ân, Hz. Âdem'den son nebîye kadar, indirilen kitaplar, sâhifeler ve ilâhî haberleri kendinde toplayan kitaptır." ${ }^{68}$ Kur'ân öyle bir kitaptır ki, bütün nebîlerin, meleklerin ilimleri ve ilmin bütün çeşitlerini içerir ve bunları ehline îzâh eder. ${ }^{69}$ İbnü'l-Arabî bu görüşe muhtemelen hadislerde Allah'ın Kur'ân'da önceki ve sonrakilerin ilmini bir araya getirdiğinin bildirilmesinden ulaşmıştır. ${ }^{70} \mathrm{O}$ halde Kur'ân'ın ilim hazinesi olmasının kapsamı indirilmiş bütün kitaplardaki ilimleri ihtivâ ettiği gibi, onlarda olmayan ilimleri de içine alacak kadar geniştir. Bu bağlamda kendisine Kur’ân verilen kimseye her ilmi ihtivâ eden kâmil ziyâ verilmiş olmaktadır. İbnü’l-Arabî bu görüşünü “Kitâbda bir şeyi eksik bırakmadık"71 âyetine dayandırır. ${ }^{72}$ Bu âyetin kapsamında düşünüldügünde Kur'ân Peygamberimiz'e verildiğinden onun ilmi bütün peygamberlerin ilmini kapsadığı gibi, bütün ilimleri de muhtevîdir.

İbnü’l-Arabî’nin Hz. Peygamber ve diğer peygamberle ilgili müstakil olarak kaleme aldığı kitabın adı "Fusûsu'l-Hikem ve Husûsu'l-Kilem" dir. ${ }^{73}$ "Hikmet ${ }^{74}$ Fasları ve Kelimelerin Husûsiyetleri” anlamına gelen eserde, İbnü'l-Arabî "fass" kelimesini bir şeyin özü, ruhu manasına kullanır. ${ }^{75}$

68. bkz. İbnü'l-Arabî, Fütûhât, 2/90.

69. bkz. İbnü'l-Arabî, Fütûhât, 2/107.

70. Ebü's-Seâdât Mecdüddîn İbnü'l-Esîr, Câmiu'l-Usûl, thk. Abdulkadir Arnavut (Dımaşk: Mektebetü'l-Halvânî, 1972), 8/464 (No. 6233).

71. el-En'am 6/38.

72. bkz. İbnü'l-Arabî, Fütûhât, 2/107.

73. Fusûs hakkında genel bilgi için bkz. Mahmud Erol Kılıç, "Fusûsu'l-Hikem” (İstanbul: TDV Yayınlar1, 1996), 13/230-237.

74. "Klasik sözlüklerde hikmet kelimesinin (çoğulu hikem) “yargıda bulunmak” anlamındaki hükm masdarından isim olduğu belirtilir; ayrıca "engellemek, alıkoymak, gemlemek; sağlam olmak” mânalarına gelen ihkâm masdarlarıyla anlam ilişkisi kurulur.”... İbn Manzûr, hikmetin özellikle Allah'a nisbeti halinde "en değerli varlıkları en üstün bilgiyle bilmek" mânasına geldiğini belirtir. Hikmet ve hüküm kelimeleri "bilmek” (ilim) ve “anlamak” (fikıh) mânalarında eş anlamlı olur."... "İsfahânî hikmet terimini "İlim ve akıl yoluyla gerçeği bulma” şeklinde tanımlar.” Geniş bilgi için bkz. İlhan Kutluer”, “Hikmet” Türkiye Diyanet Vakfi İslâm Ansiklopedisi (İstanbul: TDV Yayınları, 1998), 17/503-506; Hikmet tasavvufta genellikle "İlâhî sırların ve gerçeklerin bilgisi, varlıkların var oluş amaçlarının kavranması, sebeplerle bunların sonuçları arasındaki ilâhî ilişkilerde ilâhî irâdenin rolünün keşfedilmesi” anlamında kullanılır. Mustafa Kara, "Hikmet” Türkiye Diyanet Vakfi İslâm Ansiklopedisi (İstanbul: TDV Yayınları, 1998), 17/518-519. 75. İbnü'l-Arabî, Fusûs, 183; Şârihler bunun bir şeyin zübdesi, lübbü, özeti manasına geldiğini söylerler. bkz. Dâvud el-Kayserî, Matla'u husûsi'l-kilem fî meânî Fusûsi'l-Hikem (Tahran: 
"Kelime” ise farklı anlamları olmakla birlikte hakîkat anlamına kullanmıştır. ${ }^{76}$ Bir peygamber için kullanıldığında ise peygamberin varlı̆̆ının hakîkati anlamına gelir. ${ }^{77}$ İbnü'l-Arabî bu eserinde her bir peygamberi bir hakîkat ile ilişkilendirerek, o hakîkat ile alakalı konuları açıklar. Bütün hakîkatleri kendinde toplayan kişi ise Peygamberimiz'dir. Bu manada Hakîkat-i Muhammediyyeyi bütün hakîkatlerin merkezi etrafında konuları açıklar.

İbnü'l-Arabî Fusûsu'l-Hikem'in “Muhammed Fassı”nda, O’nun insan türü içinde en mükemmel varlık olması hasebiyle hikmetinin ferdiyet/ teklik olduğunu belirtir. Fusûs şârihlerinden Dâvud el-Kayserî, İbnü'lArabî’nin ferdiyet hikmetini Hz. Peygamber ile ilişkilendirmesini, bütün ilâhî isimleri içine alan Allah isminin mazharı oluşu ile açıklar. Aynı zamanda Peygamberimiz, üzerinde Zât-ı Ahadiyye'den başka mertebenin bulunmadığı İlâhî cem'iyet makâmının tek sâhibidir. ${ }^{78}$ Ferdiyet hikmeti varlığın onunla başlayıp yine onunla son bulmasını gerektirir. İbnü’lArabî̀nin bu görüşüne delili ise Hz. Peygamber'in “Âdem su ve toprak arasında iken nebî olması" "79 yani rûhen ilk nebî ve unsûrî yaratılışıyla ise son nebî oluşudur. Peygamber olarak rûhânî varlığı ile bütün peygamberlerin rûhlarına peygamber olarak gönderildiği gibi, unsûrî varlığg ile de onların sonuncusudur. ${ }^{80}$ İbnü'l-Arabî, Hz. Peygamberin bütün peygamberlerden önce ve aynı zamanda sonra oluşunu dâire metaforuyla izah eder. Bir dâire çizildiğinde başlangıç sona bitişik olacaktır. Bunun metafizikte anlamı Allah Teâlâ'nın el-Evvel, el-Âhir, el-Bâtın ve ez-Zâhir isimlerinin bir gereği olup varlığın başladığı yere dönmesi demektir. İbnü'l-Arabî'ye göre peygamberlik için de durum aynıdır. Hz. Resûlüllah ile peygamberlik bâtında başlamış, zâhirde de yine onunla son bulmuştur.

Dâru'l-Îtisâm, 1416), 1/323; Sainüddin Ali. b. Muhammed et-Türke, Şerhu Fusûsi'l-Hikem, haz. Muhsin Beydarfer (Kum: İntişârât-1 Baydar, 1378), 2/774; Konuk, Fusûsu'l-Hikem Tercüme ve Şerhi, 4/41.

76. bkz. İbnü'l-Arabî, Fusûs, 57.

77. Konu ile ilgili bkz. Hakîm Mu'cemu's-Sûfî̀, 978.

78. Kayserî, Matla'u husûsi'l-kilem, 2/1153.

79. Sehâvî ve Zerkeşî hadisin bu lafızla aslının olmadığını söylemiştir. bkz. İsmâil b. Muhammed Aclûnî, Keşfu'l-Hafâ, thk. Ahmed Kalaş (Haleb: Mektebetü't-Türasi'l-İslâmî, ts.), 2/1012 (No. 2017). Ancak hadis "Âdem ruh ve cesed arasındayken ben nebî idim.” şeklinde sahih olarak mevcuttur. bkz. Tirmizî, "Menâkıb”, 1; İbn Mâce, “Tıb”, 45.

80. bkz. İbnü’l-Arabî, Fusûs, 215. 
Bu demektir ki peygamberlik önceden de sonradan da hakîkat yönünden ona âittir. ${ }^{81}$

İbnü'l-Arabî peygamberlerin hakîkatini anlatırken, her bir hakîkate "kelime" 82 adını verir. Ona göre kelimenin çoğulu olarak "kelim"in bir anlamı da isimlendirilenlerin hakîkatleri demektir. ${ }^{83} \mathrm{Bu}$ durumda Hakîkat-i Muhammediyye bütün peygamberlerdeki kelimelerin (hakîkatlerin) tamâmıdır. Çünkü ona göre hadîste geçen "cevâmiu'l-kelim" ${ }^{84}$ tâbîri Hz. Peygamber'in hakîkatleri kendinde toplama özelliğini ifâde eder. İbnü’l-Arabî bu anlamda "cevâmiu'l-kelim” tabirine eserlerinde genişçe yer verir. ${ }^{85} \mathrm{~Hz}$. Peygamber'e verilen kelimeye "kelime-i câmia" da denir. Bu durumda birer kelime olan bütün peygamberlerin kelimelerini kendinde bir araya getirmiş olan kişi yine Peygamberimiz olmaktadır. ${ }^{86}$

İbnü'l-Arabî, Hz. Peygamberin bütün peygamberlerden önce ruhen nebî olmasını cevâmiu'l-kelim oluşu ile de irtibatlandırır. Bu manada Peygamberimiz'in her biri bir kelimeden oluşan peygamberlerin öncüsü olması ve onlara gönderilmesi için, bütün kelimelerin kendisinde var olması gerekmektedir. ${ }^{87}$ Âyette Hz. Îsâ'dan "Meryem'e ilkâ ettiği kelimesidir" şeklinde bahsedilmesinden hareketle varlı̆̆ın hakîkatlerinin, Hakk’ın

81. bkz. İbnü'l-Arabî, Fütûhât, 3/413.

82. A. Avni Konuk kelime hakkında şu bilgileri verir: "Kelim, "kelime"nin cem'idir. Ve "kelime"den murâd "her bir mevcûdun "ayn"ıdır. Zîrâ onlar nefes-i rahmânî ile zuhûr etmiştir. Nitekim insanın hîn-i tekellümünde, kelimât nefes-i insânî ile zâhir olur. Cenâb-1 Şeyh (r.a.) Fütûhât-ı Mekkiyye'nin yüz doksan sekizinci bâbında / buyururlar ki "Mevcûdât bitmek tükenmek bilmeyen kelimâttır." Allah Teâlâ, vücûd-i Hz. Îsâ (a.s.) hakkında "Meryem’e ilkā ettiği kelimesidir." (en-Nisâ 4/171) buyurdu. Ve mevcûdâtın kelimât olduğuna Hak Teâlâ Hazretleri'nin "De ki: Rabbimin kelimeleri için deryâ mürekkep olsa ve bir o kadar da ilâve getirsek dahi, Rabbimin kelimeleri bitmeden önce deniz tükenecektir. (el-Kehf 18/109) kavl-i şerîfi delildir. Ve Şeyh-i Ekber efendimizin burada "kelim"den murâd-ı âlîsi, atyeb-i kelimât-1 ilâhiyye olan enbiyâa (aleyhimü's-selâm)'ın zevât-1 şerîfeleridir...' Konuk, Fusûsu'l-Hikem Tercüme ve Şerhi, 1/91 Kelime ilgili bir değerlendirme için ayrıca bkz. Ebü'l-A'la Afîfî,, "Müslümanların Logos Nazariyeleri” İslâm Düşüncesi Üzerinde Makaleler içinde, çev. Ekrem Demirli (İstanbul: İz yayınları, 2000), 61-107; M. Mustafa Çakmaklığlu, İbnü̉l-Arabî’de Mârifetin İfâdesi (İstanbul: İnsan Yayınları 2007), 297-310.

83. bkz. İbnü'l-Arabî, Fütûhât, 3/556.

84. Muhammed b. İsmâil el-Buhârî, el-Câmiu's-Sahîh, thk. Mustafa Dîb (Beyrut: Dâru İbn Kesîr, 1987); 6/2654 (No. 6845); Müslim b. el-Haccâc, Sahîh-i Müslim, thk. Mahmûd Fuâd Abdulbâkî (Beyrut: Dâru İhyâi't-Türâsi'l-Arabî, ts.), 1/375 (No. 523).

85. bkz. İbnü'l-Arabî, Fusûs, 71, 73, 215; İbnü'l-Arabî, Fütûhât, 1/3, 71, 80; 2/50, 72.

86. bkz. İbnü'l-Arabî, Fütûhât, 2/363.

87. bkz. İbnü'l-Arabî, Fütûhât, 3/556.

88. en-Nîsâ $4 / 171$. 
kelimeleri olduğunu ve onların tükenmeyeceğini belirtir. Peygamberimiz için isimler ve müsemmâlar hasıl olduğundan bütün hayrı kendinde toplamıs ve bütün insanların efendisi olmayı hak etmiştir. "Ben kıyâmet günü insanların efendisiyim" ${ }^{89}$ hadîsinde belirtildiği gibi Peygamberimiz, diğer peygamberlerin de efendisidir. ${ }^{90}$

Fusûs şârihlerinden el-Cendî, Hz. Peygamber'e verilen cevâmiu'l-kelimi Hz. Âdem'e tâlîm edilen esmâların müsemmâsı olan ilâhî kelimeler olarak yorumlar. ${ }^{91}$ İbnü'l-Arabî̀ye göre Hz. Muhammed bu isimlerin mânâlarına sahipti. Hz. Âdem ise bu isimleri taşıyan kişiydi. Hz. Peygamber esmâ-i ilâhiyyenin bir başka deyişle ilâhî kelimelerin, hakîkatlerin tamâmının asıl mazharıdır. ${ }^{92}$

İbnü'l-Arabî ayrıca hadîste geçen "kelimeler"i varlıklar olarak yorumlar. Bu manada bütün âlem Allah'ın kelimeleri olup, Allah kelimelerindeki hikmeti Hz. Muhammed'e vermiştir. Risâlet ve nübüvvet açısından $k e-$ limeleri değerlendiren İbnü'l-Arabî, Hz. Peygamberin vazifesinin bütün kelimeleri yani varlıkları kapsadığına ve vazifesinin umûmî oluşuna işaret kabul eder. Onun bu yaklaşımı Hz. Peygamber'in âyetteki “âlemlere

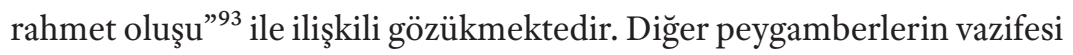
ise hususidir. Peygamberimiz'in bütün peygamberlerdeki kelimeleri yani hakîkatleri kendinde birleştiren kişi “cevâmiül-kelim" olması da yine vazifesinin umûmîliğine işârettir. ${ }^{94}$

İbnü'l-Arabî̀nin Hz. Peygamber ve diğer peygamberler arasındaki ilişki konusunda ayrıca “zevk” dikkat çeker. Ona göre Her peygamberin bir zevki vardır. Bu zevk İbnü’l-Arabî’de günlük dilde kullandığımız mananın üstünde bir anlam ifade eder. Ona göre zevkten kasıt, o peygamberde Hakk'in ilâhî tecellîsinin sonucu ortaya çıkan ilk haldir. ${ }^{95}$ Peygamberlerdeki zevkin farklılığı ise tecellînin farklığından kaynaklanır. Zevk tecellîye bağlı olarak gerçekleştiği için, tecellî netîcesinde ortaya çıan ilimler, zevkî ilimlerdir. Bir ilim tecellîden kaynaklanmıyorsa

89. Tirmîzî, Sünen, 5/48 (No. 3148); İbn Mâce, Sünen, 2/1440 (No. 4308).

90. bkz. İbnü'l-Arabî, Fütûhât, 3/556.

91. Müeyyidüddîn el-Cendî, Şerhu Fusûsi>l Hikem (Meşhed: Danişgâh-1 Meşhed, 1982), 709.

92. bkz. İbnü'l-Arabî, Fütûhât, 1/109, Ayrica bkz. Cîlî, el-İnsânu'l-Kâmil, 49.

93. el-Enbiyâ 21/107.

94. bkz. İbnü'l-Arabî, Fütûhât, 3/413.

95. bkz. İbnü'l-Arabî, Fütûhât, 2/548. 
ona zevkî ilim de denemez. ${ }^{96}$ İbnü’l-Arabî zevkleri taksim ederek şöyle der: "Resûllerin zevkleri, resûllere mahsûstur. Nebîlerin zevkleri nebîlere, velîlerin zevkleri de velîlere mahsûstur. Bâzı resûller, bütün bu üç zevkin sâhibidirler. Çünkü onlar hem resûl, hem nebî, hem de velîdirler." Konunun anlaşılması için Hz. Mûsâ ile Hızır'ı örnek verir. Kur'ân'da Hz. Mûsâ hakkında kullanılan ve zevk anlamına gelen "hibrâ"97 kelimesi ona göre tam da peygamberler hakkında bahsettiği zevkin yani tecellîler sonucu ortaya çıkan ilmin karşıllı̆ıdır. İbnü’l-Arabî’nin dikkat çektiği zevklerin farklılığı hususu, Hz. Mûsâ ve Hızır için “Allah'ın her ikisine öğrettiği ilmin farklı olup, biri diğerinin ilmini bilmedikleri” şeklinde bir hadiste açıklık kazanmaktadır. ${ }^{98}$ Konuya tekrar dönecek olursak, Hızır ona kendisiyle birlikteliğe sabredemeyeceğini söylemiş, bunun sebebi olarak da işin iç yüzünü kavrayamayacak durumda olmasını göstermiştir. İbnü’l-Arabî Hz. Mûsâ'nın bu durumunu ilk bakışta anlaşılan şekliyle bir eksiklik olarak değil, ilâhî tecelliden kaynaklanan zevklerinin farklı olmasıyla açıklamıştır. O halde âyetin mânâsı Hz. Mûsâ’nın zevkinin olmadığı ve zevkî ilimle öğrenmediği bir şey hususunda sabır da göstermesinin mümkün olmadığı şeklide olmaktadır. ${ }^{99}$ Dolayısıyla Hz. Mûsâ’nın, Hz. Hızır’a âit makamdan bir zevki olmadığı gibi, Hızır'ın da Mûsầya âit makamdan bir zevki yoktur. ${ }^{100}$ İbnü'l-Arabî̀nin zevk ile ilgili bu açıklamalarından, Muhammedî zevkin bütün diğer peygamberlerin zevkini kendinde toplayan bir zevk olduğu sonucu çıkarılabilir.

İbnü'l-Arabî’nin, Hz. Peygamber'in diğer peygamberlerle ilişkisi konusuna açıklık getirdiği bir başka husus da "mizâce"/yaratılıştır. Bu açıdan Hz. Muhammed bütün nebî ve resûllerdeki mîzâcları ihtivâ eden bir mizâcâ sâhip olduğu için bütün insanlara gönderilmiştir. Diğger peygamberlerin mîzâcı Hz. Peygamber'e göre belirli bir yönden tebârüz ettiği için belirli bir kavme gönderilmişlerdir. ${ }^{101}$ Aynı şekilde Hz. Peygamber'in şeriatı da

96. Hakîm, Mu'cem, 493-494.

97. el-Kehf 18/68.

98. Buhârî, Sahîh, 1/35 (No. 122).

99. İbnü'l-Arabî, Fütûhât, 2/51.

100. İbnü'l-Arabî, Fütûhât, 1/199; Yeri gelmişken İbnü'l-Arabi’nin Peygamberlerdeki bu zevk farklılığının, onların vârislerine de etki ettiği ve dolayısıyla zevkleri farklı olduğunu belirtiğini de hatırlamakta yarar vardır. bkz. İbnü'l-Arabî, Fütûhât, 1/223.

101. bkz. İbnü'l-Arabi, Fütûhât, 3/431. 
cevâmiu'l-kelim olması yani küllı̂ hakikatleri içermesinden dolayı bütün şerîatları kapsayıcı bir şekilde gelmiştir. ${ }^{102}$

İbnü'l-Arabî’nin Hz. Peygamber ve diğer peygamberler için kullandığı başka bir tabir de "felek"tir. Felek kavramı İbnü'l-Arabî̀nin irfânında çok boyutlu anlamlar kazanmıs temel kavramlardan biri olarak karşımıza çıkar. ${ }^{103}$ Ona göre, her peygamber bir feleğe benzemekte olup, peygamberler içerisinde Hz. Peygamberin feleğinden daha geniş feleği olan yoktur. ${ }^{104} \mathrm{~Hz}$. Peygamber'in "velî" olmasını da felek ile birleştiren İbnü'l-Arabî, velâyeti felek-i muhit/en kapsayıcı felek ${ }^{105}$ ve dâire-i kübrâ/ en büyük daire olarak tasavvur eder. ${ }^{106}$

İbnü'l-Arabî, Peygamberimiz ve diğer peygamberlerin onunla ilişkisi ile ilgili manevi "haz" (pay, nasib) konusuna da yer verir. Her bir peygamberin Allah'tan bir hazzı, nasibi vardır. Hz. Muhammed'in hazzını cem' makamından değerlendiren İbnü'l-Arabî, bu üst bakışla bütün peygamberlerde bulunan hazzın onun hazzı olduğunu, her birine hazzın ondan geldiğini söyler. Bu bakımdan haz aslında tek olup o da Muhammedî hazdır. Fark makamından değerlendirdiğinde ise her bir peygamberin hazzı ile Hz. Muhammed'in hazzı arasında yetmiş sekiz haz ve makam bulunmaktadır. Bu duruma Hz. Peygamber'in Hz. Âdem'le ilişkisinin hem zâhir hem de bâtın ilişkisi olmasını örnek gösterir. Bu ilişki Rasûlüllah'ın bâtın açısından ondan önce peygamber olması, zahir açısından ise sonra peygamber olması şeklinde anlaşılabilir. İbnü’l-Arabî̀ye göre Hz. Peygamber'in diğer peygamberler ile haz açısından ilişkisi o kadar geniş bir konudur ki, her bir peygamber ile Hz. Muhammed arasındaki hazzın bilinmesi için, her birinin hazzını belirlemek amacıyla 124 bin peygamber sayısınca bölüm açmak gerekir. Ameller açısından da hazlara değinen İbnü’l-Arabî onların yetmiş dokuz olmak üzere bilindiğini belirtir. Peygamberlerden her biri için tek, iki, on, dokuz, sekiz veya daha az ya da daha çok haz/nasip

102. bkz. İbnü'l-Arabî, Fütûhât, 1/138.

103. Genel olarak devreden her şeye felek denmektedir. Muhammed Murtazâ ez-Zebîdî, Tâcü'l-Ârus min cevâhiri'l-kâmus, thk. Ali eş-Şiri (Beyrut: Dârü'l-Fikr, 1994), 1/6767; Felek, sâdece zâhiri olduğu gibi bâtınî de olur. bkz. Seyyid Şerîf el-Cürcânî, Ta'rîfât, thk. İbrâhim Ebyâr (Beyrût: Dâru'l-Kitâb el-Arabî, 1405/1985), 1/217. İbnü'l-Arabî burada mânevî anlamda kullanmıştır. Geniş bilgi için bkz. Veysel Akkaya, Şeyhi Ekber İbn Arabî̀de İdrîs Peygamber (İstanbul: Erkam yayınları, 2010), 68-73.

104. bkz. İbnü'l-Arabî, Fütûhât, 2/144.

105. İbnü'l-Arabî, Fütûhât, 3/14.

106. İbnü'l-Arabî, Fütûhât, 2/256. 
olup, hazların tamamına sahip olan sâdece Rasûlüllah'tır. Bundan dolayı diğer peygamberler husûsî olarak kendi kavmine, Hz. Peygamber ise umûmî olarak bütün insanlara gönderilmiştir. ${ }^{107}$

\section{Sonuç}

İbnü'l-Arabî Nûr-i Muhammedî/hakîkat-i Muhammedîyye konusunu Kur'ân ve Sünnet'te yer alan "nûr” kavramı çerçevesinde değerlendirmiştir. Bu bağlamda ilk dönemden itibaren müfessirler ve sûfîler nûr ile ilgili âyetlerde Hz. Peygamber'in nûruna dikkat çekmişlerdir.

Hadislerde insanların ve hattâ bütün varlıkların içerisinde en üstün olduğu bildirilen Rasûlüllah'ın, tabiî olarak Allah’ın bütün isimleri gibi en-Nûr isminin de en büyük tecellisine mazhar olduğunu söylemek mümkündür. Aynı şekilde Muhammedî nûrun, âlemlere rahmet olması itibariyle bütün varlıklarla ilişkili olduğu düşünülebilir.

Nûr-i Muhammedî ile ilgili en kapsamlı ve orijinal bilgiler İbnü'lArabî̀ye aittir. O konuya Varlık ve mertebeleri bağlamında açıklık getirmiştir. İlk yaratılan varlığın, bir başka deyiş ile Varlık’ın ilk tecellîsini Nûr-i Muhammedî olarak anlatan İbnü'-Arabî, bu bağlamda ilk yaratılan varlık ile ilgili akıl, kalem, ruh gibi isimlendirmelerin, aslında tek olan hakîkatin farklı özelliklerinden dolayı aldı ğ

İbnü'l-Arabî Nûr-i Muhammedî’nin diğer varlıklar ile ilişkisini, Nûr-i Muhammedî ve diğer peygamberlerin nûru üzerinden anlatmıştır. Bu hususta yazdığı meşhur eseri Fusûsu'l-hikem'in temel kurgusu, Nûr-i Muhammedî ve onun etrafında diğer peygamberlerin nûrlarıdır. İbnü'lArabî bu ilişkiyi ilâhî isimler bağlamında açıklar. Hz. Peygamber Allah’ın bütün isimlerinin kâmil mazharı iken, diğer her bir peygamber Allah’ın bazı isimlerinin kâmil mazharıdır.

İbnü'l-Arabî eserlerinde nübüvvetin Hz. Peygamber ile başlayıp yine onunla bittiğini izah ederken bunu miftah ve hatem oluşuyla açıklamıştır. Çünkü Ekberî irfanda ilk, aynı zamanda son demektir.

107. bkz. İbnü’l-Arabî, Fütûhât, 2/87-88; Bütün bu açıklamalardan sonra, Nûr-i Muhammedî açısından her mü'min için Hz. Peygamber'e salavât getirmenin, onun nûru ile irtibat kurmasını sağladığını belirtmekte yarar vardır. Bu konuda geniş bilgi için bkz. Zehra Çelebi, Tasavvuf Târihinde Vird-Hizb Geleneği ve İsmâil Hakkı Bursevî’nin Şerh-i Salavât-ı Meşîyye İsimli Eseri (Konya: Selçuk Üniversitesi, Sosyal Bilimler Enstitüsü, Yüksek Lisans Tezi, 2007), 64-75; Frithjof Schuon, İslâmı Anlamak, çev. Mahmut Kanık (İstanbul: İz yayınları, 1999), 130-137. 
İbnü’l-Arabî, Hz. Peygamber'in diğer peygamberlerle ilişkilerini, âyetler ve hadisler ışı̆̆ında incelemiştir. Bu konuda âyetlerdeki Peygamberimiz ve diğer peygamberlerle ilgili özellikleri, orijinal bir şekilde mezcederek âdetâ bir bütünün parçalarını toplamış ve âyette belirtildiği gibi onların hiçbirini diğerinden ayırt etmeden ${ }^{108}$ yorumlamıştır.

İbnü'l-Arabî’nin nûr-î Muhammedî açısından, Hz. Rasûlüllah ve diğer peygamberlerin ilişkisini anlatırken üzerinde durduğu temel husus, Hz. Peygamber'in merkezde, diğer peygamberlerin de onun etrafında yer almalarıdır. Bu konuda Peygamberimiz'in âlemlere rahmet oluşu, meselenin özünü teşkil eder. Çünkü bu rahmet geçmişi de kapsadığı için, Rasûlüllah'ın bütün peygamberlere de rahmet olarak peygamberliği umumidir.

İbnü'l-Arabî Peygamberimiz ve diğer peygamberler arasındaki ilişkiyi, âyetlerde sîrac/kandil, mişkât/lamba, kelime, zevk; hadislerde cevâmiu'l-kelim, ilk nebî oluşu çerçevesinde, ayrıca mizaç, felek ve haz yönünden de inceleyerek geniş bir perspektifle ortaya koymuştur. Netice itibariyle Nûr-i Muhammedî diğer bütün nebîlerin nûrlarının kaynăğ olup, her bir nebînin nûru o nûrdan nasîbi ölçüsündedir. Bir başka deyişle Muhammedî hakîkat, şerîat ve zevk diğer peygamberlerdeki hakîkat, şerîat ve zevkin menbaidır.

Çıkar Çatışması / Conflict of Interest: Yazarlar çıkar çatışması olmadı̆̆ını beyan etmiştir. / The authors declared that there is no conflict of interest.

Finansal Destek / Grant Support: Yazarlar bu çalışma için finansal destek almadıklarını beyan etmiştir. / The authors declared that this study has received no financial support.

\section{Kaynakça}

Addas, Claude. İbn Arabi. çev. Atila Ataman. İstanbul: Gelenek Yayıncılık, 2003.

Afîfî, Ebü’l-A’la. İslâm Düsüncesi Üzerinde Makaleler. çev. Ekrem Demirli. İstanbul: İz yayınları, 2000.

Afîfî, Ebü'l-A'la. Fusûsü’l-hikem liş-Şeyhi'l-Ekber Muhyiddîn b. Arabîve’t-ta'likâtu aleyh. Beyrut:

Dârü'l-Hayât, 1946.

Akkaya, Veysel. Şeyhi Ekber İbn Arabî'de İdrîs Peygamber. İstanbul: Erkam yayınları, 2010.

108. el-Bakara 2/285. 


\section{Sufine}

200

Veysel AKKAYA

Akman, Mustafa. "Hakikat-ı Muhammedi Düşüncesi ve Bu Düşüncenin Referanslarını Aktaran İki Kaynak ve Müellifleri”. Yalova Sosyal Bilimler Dergisi 2/2 (2011), 111.

Akpınar, Soner. “Oryantalist Düşüncede Hakîkat-i Muhammediyye Algısı”. Ignaz Goldziher ve Annemarie Schimmel Örneği. Kahramanmaraş Sütçü İmam Üniversitesi İlahiyat Fakültesi Dergisi 16/ 32 (2018), 279-309.

Al-Hallâj, Ebu'l-Mugis el-Hüseyn b. Mansûr. Kitâb al-Tawâsin/Kitâbu't-Tavâsîn. Préparé Louis Massignon, Paris: Librairie Paul Geuthner, 1913.

Ay, Mahmut. “İşari Tefsirlerde Hakikat-i Muhammediyye Anlayışı”. Darulfunun İlahiyat İstanbul Üniversitesi İlahiyat Fakültesi Dergisi 23/2 (2010), 111.

Besbah, Ahmed Hasan. en-Nâbigatü'l-Ca’di. Beyrut: Dârü'l-Kütübi'l-İlmiyye, 1994.

Chodkiewicz, Michel. "Seal of the Saints: Prophethood and Sainthood in the Doctrine of Ibn ‘Arabi”. çev. Liadain Sherrard. Lahore: Suhail Academy, 2001.

Çakmaklığlu, M. Mustafa. İbnül-Arabî'de Mârifetin Iffâdesi. İstanbul: İnsan Yayınları 2007.

Çelebi, Zehra. Tasavvuf Târihinde Vird-Hizb Geleneği ve İsmâil Hakkı Bursevînnin Şerh-i Salavât-ı Meşîyye İsimli Eseri. Konya: Selçuk Üniversitesi, Sosyal Bilimler Enstitüsü, Yüksek Lisans Tezi, 2007.

Çelik, Ömer. “Kur'ân-1 Kerîm'de Nûr Kavramı”. Marmara Üniversitesi İlahiyat Fakültesi Dergisi 16-17 (1998-1999), 149-155.

Çift, Salih. “İlk Dönem Tasavvuf Düşüncesinde Nûr Kavramı”. Uludă̆ Üniversitesi İlahiyat Fakültesi Dergisi 13/1 (2004), 144-146.

Demirci, Mehmet. "Hakîkat-i Muhammediyye”. Türkiye Diyanet Vakfı İslâm Ansiklopedisi. 27/179-180. İstanbul: TDV Yayınlar1 1997.

Demirci, Mehmet. "Nûr-i Muhammedî”. Dokuz Eylül Üniversitesi İlahiyat Fakültesi Dergisi 1 (1983), 239-258.

Döner, Nuran. Tasavvuf Kültüründe Hz. Peygamber Tasavvuru. Bursa: Uludağ Üniversitesi, Sosyal Bilimler Enstitüsü, Doktora Tezi, 2007.

Ebû Ziyab, Halil İbrâhim. en-Nâbiga el-Ca’di. Dımaşk: Dârü’l-Kalem, 1987.

Aclûnî, Muhammed b. İsmâil. Keş̧fu'l-Hafâ. thk. Ahmed Kalaş. Haleb: Mektebetü’t-Türasi'l-İslâmî, ts.

Askalânî, İbni Hacer. el-Metâlibü’l-âliye. thk. Habiburrahman el-A'zamî. Kuveyt: el-Matbaatü'lAsriyye, 1973.

Aynî, Bedreddin. Umdetü’l-Kârîşserhi Sahihi'l-Buhari. Kahire: İdâretü’t-Tıbâati'l-Münîriyye, ts. Beyhakî, Ahmed b. Hüseyin. Şuabu'l-İman. Beyrut: Dâru'l-Kütübi'l-İlmiyye, 1410.

Buhârî, Muhammed b. İsmâil. Câmiu’s-Sahîh. thk. Mustafa Dîb. Beyrut: Dâru İbn Kesîr, 3. basım, 1987. Cendî, Müeyyidüddîn. Şerhu Fusûsi l Hikem. Meşhed: Danişgâh-1 Meşhed, 1982.

Cezâirî, Abdülkâdir. Buğyetü’t-Tâlib alâ Tertîbi't-Tecellî bi Külliyyeti'l-Merâtib. haz. Asım İbrahim el-Keyyali. Beyrut: Darü'l-Kütübi'l-İlmiyye, 2004/1425.

Cîlî, Abdülkerim. el-İnsânu'l-Kâmil. Beyrût: Dâru'l-Kütübü'l-İlmiyye, 1997 
Cîlî, Abdülkerîm. İnsân-ı Kâmil. çev. Abdülaziz Mecdi Tolun. haz. Selçuk Eraydın vd. İstanbul: İz yayınlar1, 2002.

Cîlî, Abdülkerîm. Şerhu Müşkilâti'l-Fütûhâti’l-Mekkiyye. thk. Yusuf Zeydan. Kâhire: Dârü'lEmin, 1999.

Cürcânî, Seyyid Şerîf. Ta’rîfât. thk. İbrâhim Ebyâr. Beyrût: Dâru'l-Kitâb el-Arabî, 1405/1985.

Gazzâlî, Ebu Hamid Muhammed b. Muhammed. Mişkâtü’l-Envâr. Beyrut: Dâru’l-Kütübi’lİlmiyye, 1994.

Gurâb, Mahmûd. Rahmetün mine’r-Rahmân. Dımaşk: Matbaatü Nazar, 1989.

Hakîm, Suad. Mu'cemu's-Sûfî. Beyrût: Dâru Nedre, 1981.

Hindî, Müttakî. Kenzü’l-Ummâl. Beyrût: Müessesetü’r-Risâle, 1989.

İsfahânî, Ebû Nuaym. Hilyetü'l-Evliyâ. Beyrut: Dâru'l-Kütübi'l-Arabî, 1405.

Kayserî, Dâvud. Matla'u husûsi'l-kilem fî meânîf-hikem. Tahran: Dâru'l-Îtisâm, 1416.

Nisaburi, Hakim. Müstedrek. thk. Mustafa Abdulkadir Atâ. Beyrut: Dâru’l-Kütübi'l-i̇lmiyye, 1990.

Eraydın, Selçuk. “Hakîkat-i Muhammediyye”. Diyânet Dergisi 25/4 (1989), 131-143.

Râzî, Fahreddîn,. Tefsîr-i Kebîr. çev. kurul, Ankara: Akçă̆ Yayınları, 1988.

Sâdık, Ca'fer. Hakâiku't-Tefsîri'l-Kur'ânî. haz. Ali Zey'ur. Beyrut: Müessesetu İzzeddin, 1993. Sehâvî, Ebü'l-Hayr Şemsüddîn. el-Makasıdü’l-hasene. thk. Muhammed Osman el-Huşt. Beyrut: Dârü'l-Kitâbi'l-Arabi, 1985.

Sülemî, Ebû Abdurrahmân. Hakâiku't-Tefsîr. thk. Gerhard Böwerıng. Beyrut: Dârü'l-Maşrık, 1995. İbnü'l-Esîr, Ebü’s-Saâdet Mecdüddîn, Câmiu'l-Usûl. thk. Abdulkadir Arnavut. Dımaşk: Mektebetü'l-Halvânî, 1972.

Taberânî, Ebü’l-Kâsım Süleymân. el-Mu'cemu'l-Evsat. Kahire: Dâru'l-Harameyn, 1415.

Taberi, Ebu Cafer. Tefsîru't-Taberî. thk. Abdulllah b. Abdulmuhsin. Riyâd: Dâru'l-âlemi’lİslâmî, 2003.

İbn Türke, Sainüddin. Şerhu Fusûsi'l-Hikem. haz. Muhsin Beydarfer. Kum: İntişârât-1 Baydar, 1378. Tüsteri, Abdullah. Tefsîrü't-Tüsterî. Beyrut, Dârü'l-Kütübi'l-İlmiyye, 2002.

Zebîdî, Muhammed Murtazâ. Tâcü'l-Ârus min Cevâhiri'l-Kâmus. thk. Ali eş-Şiri, Beyrut: Dârü'l-Fikr, 1994.

Goldziher, Ignaz. “Hadis'te Yeni Eflatuncu ve Gnostik Unsurlar”. çev. Ömer Özsoy. Ankara Üniversitesi İlahiyat Fakültesi Dergisi 36 (1997), 405-421.

İbn Kesir, Ebü>l-Fida İmadüddin. Tefsirü'l-Kur'âni'l-azim. thk. Muhammed Hüseyin Şemsüddin, Beyrut: Dâru'l-Kütübi'l-İlmiyye, 1998.

İbnü'l-Arabî. Muhyiddin. Fusûsu'l-Hikem. thk. Ebu'l-Alâ Afîfî. Tahran: İnşârâtü'z-Zehrâ, 2. baskı, 1370. İbnü’l-Arabî. Muhyiddin. el-Fütûhâtü’l-Mekkiyye. Beyrût: Dâru Sâdır, ts.

İbnüll-Arabî. Resâilü İbn Arabî: Kitâbu'l-Mesâil. haz. Muhammed Abdülkerim en-Nemrî. Beyrût: Dâru'l-Kütübi'l-İlmiyye, 2004. 


\section{Sufine}

202

Veysel AKKAYA

İbnü’-Arabî, Resâilü İbn Arabî: Risâletü’l-Envâr. haz. Muhammed Abdülkerim en-Nemrî Beyrût:

Dâru'l-Kütübi'l-İlmiyye, 2004.

İbnül-Arabî. Muhyiddin. Ukletüll-müstevfiz. Beyrut: Dâru'l-Kütübi'l-İlmiye, 2005.

Kâdî İyâz. Kitâbü'ş-şifa bi-ta'rifi'l-hukuki'l-Mustafa. Kahire: Dâru'l-Hadîs, 1977.

Kâdî İyâz. Şifa-i Şerif. çev. Mehmet Yaşar Kandemir. İstanbul: Tahlil Yayınları, 2012.

Kara, Mustafa. "Hikmet” Türkiye Diyanet Vakfi İslâm Ansiklopedisi. 17/518-519. İstanbul: TDV

Yayınları, 1998.

Karimov, Azat. Kur'ân'da Nur Kavramı. Ankara: Ankara Üniversitesi, Sosyal Bilimler Enstitüsü, Yüksek Lisans tezi, 2012.

Kâşânî, Abdürrezzak. Letâifu'l-A'lâm. tsh. Mecîd Hâdîzâde. Tahran: Merkez-i Neşr-i Mîrâs-1 Mektûb, 2000.

Kılıç, Mahmud Erol. Muhyiddin İbnü’-Arabî. Türkiye Diyanet Vakfı İslâm Ansiklopedisi. 20/496497. İstanbul: TDV Yayınları, 1999.

Kılıç, Mahmud Erol. Şeyh-i Ekber İbn Arabi Düşüncesine Giriş. İstanbul: Sufi Kitap, 2009.

Konuk, Ahmet Avni. Fusûsu’l-Hikem Tercüme ve Şerhi. 4 Cilt. İstanbul: Marmara Üniversitesi İlahiyat Fakültesi Vakfı yayınları, 1996.

Kutluer, İlhan. “Felsefe ile Tasavvuf Arasında: Gazzâlî’nin Mişkatü’l-Envar'ında Entellektüel Perspektifler”. 900. Vefat Yılında İmam Gazzâlî: Milletlerarası Tartışmalı İlmi Toplantı. 577-519. İstanbul: Marmara Üniversitesi İlahiyat Vakfı Yayınları, 2012.

Kutluer, İlhan. "Hikmet”. Türkiye Diyanet Vakfi İslâm Ansiklopedisi. 17/503-506. İstanbul: TDV Yayınları, 1998.

Mukâtil b. Süleyman. Tefsîru Mukâtil b. Süleyman. thk. Abdullah Mahmud. Beyrut: Dâru İhyâi't-Türâs, 1423/2002.

Müslim b. Haccâc. Sahîh-i Müslim. thk. Mahmûd Fuâd Abdulbâkî. Beyrut: Dâru İhyâi'tTürâsi'l-Arabî, ts.

Okudan, Rifat. "Hakikat-i Muhammediyye: Felsefî Temelleri ve Dînî Asıllarının Değerlendirilmesi”. Süleyman Demirel Üniversitesi İlahiyat Fakültesi Dergisi 11/2 (2003) 158-160.

Okudan, Rifat. “Hz. Peygamber'den İlk Yaratılan Şey Hakkında Rivayet Edilen Hadisler Işı̆̆ında Hakikat-i Muhammediyye”. VI. Kutlu Doğum Sempozyumu. 165-178. (Isparta: SDÜ İlahiyat Fakültesi İslâm Felsefesi Ana Bilim Dalı, 2006)

Schimmel, Annemarie. ve Muhammed Onun Elçisi'dir. çev. Ekrem Demirli. İstanbul: Kabalcı Yayınevi 2011.

Schuon, Frithjof. İslâmı Anlamak. çev. Mahmut Kanık. İstanbul: İz yayınları, 1999.

Tüccar, Zülfikar. “Nâbiga el-Ca'dî”. Türkiye Diyanet Vakfi İslâm Ansiklopedisi. 32/260-261. İstanbul: TDV Yayınları, 2006. 